\title{
Upaya Meningkatkan Kemampuan Menghitung melalui Media Konkret Koin Warna (Kancing) pada Mata Pelajaran Matematika Madrasah Ibtidaiyah
}

\author{
Mulyawati \\ Institut Agama Islam Darussalam (IAID), Ciamis-Jawa Barat \\ Email: mulyawati12@gmail.com \\ Tanto Aljauharie Tantowie \\ Institut Agama Islam Darussalam (IAID), Ciamis-Jawa Barat \\ Diki Najib Fuadi \\ Institut Agama Islam Darussalam (IAID), Ciamis-Jawa Barat
}

\begin{abstract}
This research is based on the low learning outcomes of students in the ability to calculate class II MIS Pasirlingga on learning Mathematics subject of Operation Mixed Count. One attempt to improve students' numeracy skills, researchers used Concrete Coins Color Media. The method used is Classroom Action Research Method (PTK) model Kurt Lewin. Data collection techniques used are observation, interview techniques, test and description analysis techniques. Based on research data and data analysis results, obtained conclusions, namely 1) the ability of teachers in designing the implementation planning of learning mathematics reached $90.17 ; 2$ ) teachers' skills in the implementation of Mathematics learning reached 90.78; and 3) student learning outcomes reach an average value of 80 . This proves that the concrete media of color coins affect the improvement of students 'counting ability and students' counting ability will influence student learning outcomes.
\end{abstract}

Keywords: learning mathematics in elementary schools, students' ability to count, concrete color coins media

\section{PENDAHULUAN}

Pendidikan adalah usaha sadar dan terencana untuk mewujudkan suasana belajar dan proses pembelajaran agar siswa secara aktif mengembangkan potensi dirinya untuk memiliki kekuatan spiritual keagamaan, pengendalian diri, kepribadian, kecerdasan, akhlak mulia serta keterampilan yang diperlukan dirinya, masyarakat, bangsa dan negara (Jumali dkk, 2008: 91). 
Dalam Undang-undang Republik Indonesia Nomor 20 Tahun 2003, tentang Sistem Pendidikan Nasional, bab II pasal 3 dikemukakan bahwa: "Pendidikan nasional berfungsi mengembangkan kemampuan dan membentuk watakserta peradaban bangsa yang bermartabat, dalam rangka mencerdaskan kehidupan bangsa dan bertujuan untuk mengembangkan potensi peserta didik, agar menjadi manusia yang beriman dan bertaqwa kepada Tuhan Yang Maha Esa, berakhlak mulia dan menjadi warga negara yang demokratis serta bertanggung jawab" (Depdiknas, 2006: 13).

Sekolah merupakan tempat atau lembaga untuk belajar dan mengajar serta tempat menerima dan memberi pelajaran (Tim Redaksi, 2008: 1286). Belajar adalah proses kegiatan secara berkelanjutan dalam rangka perubahan perilaku peserta didik secara konstruktif, hal ini sejalan dalam Undang-Undang Sistem Pendidikan Nasional Nomor 20 Tahun 2003. Perubahan tersebut dikelompokkan menjadi tiga aspek, yaitu aspek kognitif, afektif dan psikomotorik (Nanang dkk, 2010: 20) yang bertujuan untuk memberikan pengetahuan yang seluas-luasnya serta meningkatkan kemampuan siswa sehingga siswa dapat mengaplikasikan dalam kehidupan sehari-hari.

Matematika sangatlah erat kaitannya dengan kehidupan sehari-hari, karena pada dasarnya matematika adalah suatu cara untuk menemukan jawaban terhadap masalah yang dihadapi manusia terutama dalam hal pengetahuan tentang menghitung. Matematika sangatlah penting dalam kehidupan sehari-hari, karena dapat membantu ketajaman berpikir secara logis (masuk akal) serta membantu memperjelas dalam menyelesaikan permasalahan.

Siswa Sekolah Dasar (SD) umurnya berkisar antara 6 sampai 13 tahun. Menurut Piaget, mereka berada pada fase operasional konkret. Kemampuan yang tampak pada fase ini adalah kemampuan dalam proses berpikir untuk mengoperasikan kaidah-kaidah logika, meskipun masih terikat dengan objek yang bersifat konkret. Dari usia perkembangan kognitif, siswa SD masih terikat dengan objek konkret yang dapat ditangkap oleh panca indera. Dalam pembelajaran matematika yang abstrak, siswa memerlukan alat bantu berupa media dan alat peraga yang dapat memperjelas apa yang akan disampaikan oleh guru sehingga lebih cepat dipahami dan dimengerti oleh siswa. Proses pembelajaran pada fase konkret dapat melalui tahapan konkret, semi konkret, semi abstrak dan selanjutnya abstrak (Heruman, 2007: 1-2).

Dalam matematika, setiap konsep yang abstrak yang baru dipahami siswa perlu segera diberi penguatan, agar mengendap dan bertahan lama dalam memori siswa, sehingga akan melekat dalam pola pikir dan pola tindakannya. Untuk keperluan inilah, maka diperlukan adanya pembelajaran melalui perbuatan dan pengertian, tidak hanya sekedar hafalan atau mengingat fakta saja, karena hal ini akan mudah dilupakan 


\section{BESTARI}

Vol. 16, No. 2, 2019

p-ISSN 1907-1337; e-ISSN 2807-6532

siswa. Pepatah Cina mengatakan, "Saya mendengar maka saya lupa, saya melihat maka saya tahu, saya berbuat maka saya mengerti".

Pelajaran Matematika sering dianggap pelajaran yang sulit bagi para siswa, khususnya siswa yang masih berusia dini hal ini karena kebanyakan pendidik dalam proses pembelajaran kurang tepat menggunakan metode, teknik dan media-media yang mampu menunjang untuk membuat suasana belajar menjadi mudah dan menyenangkan bagi siswa dan yang akan mampu meningkatkan keterampilan menggunakan berbagai konsep matematika dalam kehidupan sehari-hari siswa.

Merujuk pada berbagai pendapat para ahli matematika SD dalam mengembangkan kreativitas dan kompetensi siswa, maka guru hendaknya dapat menyajikan pembelajaran yang efektif dan efisien, sesuai dengan kurikulum dan pola pikir siswa. Dalam mengajarkan matematika, guru harus memahami bahwa kemampuan setiap siswa berbeda-beda, serta tidak semua siswa menyenangi mata pelajaran matematika.

Konsep-konsep pada kurikulum matematika SD dapat dibagi menjadi tiga kelompok besar, yaitu penanaman konsep dasar (penanaman konsep), pemahaman konsep dan pembinaan keterampilan. Memang, tujuan akhir pembelajaran matematika di SD yaitu agar siswa terampil dalam menggunakan berbagai konsep matematika dalam kehidupan sehari-hari. Akan tetapi, untuk menuju tahap keterampilan tersebut harus melalui langkah-langkah benar yang sesuai dengan kemampuan dan lingkungan siswa. Berikut ini adalah pemaparan pembelajaran yang ditekankan pada konsep-konsep matematika.

Penanaman konsep dasar (penanaman konsep), yaitu pembelajaran suatu konsep baru matematika, ketika siswa belum pernah mempelajari konsep tersebut. Kita dapat mengetahui konsep ini dari isi kurikulum, yang dicirikan dengan kata "mengenal". Pembelajaran penanaman konsep dasar merupakan jembatan yang harus dapat menghubungkan kemampuan kognitif siswa yang konkret dengan konsep baru matematika yang abstrak. Dalam kegiatan pembelajaran konsep dasar ini, media atau alat peraga diharapkan dapat digunakan untuk membantu kemampuan pola pikir siswa.

Pemahaman Konsep, yaitu pembelajaran lanjutan dari penanaman konsep, yang bertujuan agar siswa lebih memahami suatu konsep matematika. Pemahaman konsep terdiri atas dua pengertian. Pertama merupakan kelanjutan dari pembelajaran penanaman konsep dalam satu pertemuan. Sedangkan kedua, pembelajaran pemahaman konsep dilakukan pada pertemuan yang berbeda, tetapi masih merupakan lanjutan dari penanaman konsep. Pada pertemuan tersebut, penanaman konsep dianggap sudah disampaikan pada pertemuan sebelumnya, di semester atau kelas sebelumnya. 
Pembinaan keterampilan,yaitu pembelajaran lanjutan dari penanaman konsep dan pemahaman konsep. Pembelajaran pembinaan keterampilan bertujuan agar siswa lebih terampil dalam menggunakan berbagai konsep matematika. Seperti halnya pada pemahaman konsep, pembinaan keterampilan juga terdiri atas dua pengertian. Pertama, merupakan kelanjutan dari pembelajaran penanaman konsep dan pemahaman konsep dalam satu pertemuan. Sedangkan kedua, pembelajaran pembinaan keterampilan dilakukan pada pertemuan yang berbeda, tapi masih merupakan lanjutan dari penanaman dan pemahaman konsep. Pada pertemuan tersebut, penanaman dan pemahaman konsep dianggap sudah disampaikan pada pertemuan sebelumnya, di semester atau kelas sebelumnya (Heruman, 2007: 2-3).

MIS Pasirlingga adalah salah satu institusi pendidikan yang di dalamnya mengajarkan Matematika sebagai bahan ajar. Seperti halnya sekolah-sekolah lainnya, MI Pasirlingga juga sudah menerapkan Kurikulum Tingkat Satuan Pendidikan (KTSP). Kurikulum Tingkat Satuan Pendidikan menuntut ketuntasan belajar sesuai dengan kondisi siswa dan sekolah, sehingga di MIS Pasirlingga Kecamatan Banjaranyar telah ditetapkan Kriteria Ketuntasan Minimal (KKM) untuk mata pelajaran Matematika di kelas II sebesar 70. Namun, keadaan yang terjadi dilapangan berdasarkan nilai ulangan harian mata pelajaran Matematika yang diperoleh siswa masih dibawah 70 atau dibawah KKM tersebut. Dari 16 siswa di kelas II sekitar 65\% atau 10 peserta didik masih mendapatkan nilai dibawah KKM dengan rata-rata nilai 67. Sehingga dapat dikatakan siswa belum memahami terhadap materi atau kompetensi dasar yang disajikan. (Sumber: Hasil wawancara dengan guru kelas II MI Pasirlingga, Sabtu 4 Maret 2017).

Tingkat kognitif siswa berbeda-beda, Peaget dalam Wowo Sunaryo mengatakan bahwa anak usia enam sampai dua belas tahun ada dalam tahapan operasional konkret. Pada tahap ini, anak sudah memiliki ciri penggunaan logika yang memadai (Sunaryo, 2011: 157). Itu berarti anak sudah mampu berpikir secara logis dalam memahami sesuatu hanya sebagaimana kenyataannya atau dengan benda-benda yang bersifat konkret.

Media konkret Koin Warna adalah media yang menggunakan benda nyata sebagai alat bantu pembelajaran. Dengan media konkret diharapkan dapat merangsang ketelitian siswa dalam menghitung sehingga siswa memperoleh jawaban yang benar dari soal operasi hitung campuran yang diberikan kepadanya. Selain itu, media konkret juga memiliki kelebihan lain seperti dapat menterjemahkan ide atau gagasan yang bersifat nyata, banyak tersedia dalam kehidupan sehari-hari karena media ini berasal dari benda-benda nyata yang ada di lingkungan sekitar siswa, mudah digunakan dan dapat digunakan pada setiap tahap pembelajaran. 


\section{BESTARI}

Vol. 16, No. 2, 2019

p-ISSN 1907-1337; e-ISSN 2807-6532

Untuk mencapai hasil yang optimum dari proses belajar mengajar, salah satu hal yang sangat disarankan adalah digunakannya pula media yang bersifat langsung dalam bentuk objek nyata (konkret) atau realia (Ibrahim \& Nana Syaodih, 2010: 118).

\section{KAJIAN TEORETIK}

\section{Pembelajaran Matematika di Sekolah Dasar}

Dalam pembelajaran matematika di tingkat SD, diharapkan terjadi reinvention (penemuan kembali). Penemuan kembali adalah menemukan suatu cara penyelesaian secara informal dalam pembelajaran di kelas. Walaupun penemuan tersebut sederhana dan bukan hal baru bagi orang yang telah mengetahui sebelumnya, tetapi bagi siswa SD penemuan tersebut merupakan sesuatu hal yang baru (Heruman, 2007: 4).

Dalam BNSP (2006: 147) matematika merupakan ilmu universal yang mendasari perkembangan teknologi modern, mempunyai peran penting dalam berbagai disiplin dan memajukan daya pikir manusia. Perkembangan pesat di bidang teknologi informasi dan komunikasi dewasa ini dilandasi oleh perkembangan matematika di bidang teori bilangan, aljabar, analisis, teori peluang dan matematika diskrit. Untuk menguasai dan mencipta teknologi di masa depan diperlukan penguasaan matematika yang kuat sejak dini.

Matematika, menurut Ruseffendi adalah bahasa simbol, ilmu deduktif yang tidak menerima pembuktian secara induktif; ilmu tentang pola keteraturan dan struktur yang terorganisasi, mulai dari unsur yang tidak didefinisikan, ke unsur yang didefinisikan, ke aksioma atau postulat dan akhirnya ke dalil. Sedangkan hakikat matematika menurut Soedjadi yaitu memiliki objek tujuan abstrak, bertumpu pada kesepakatan dan pola pikir yang deduktif (Heruman, 2007: 1).

Menurut Paling dalam Abdurrahman (2003: 252), matematika adalah suatu cara untuk menemukan jawaban terhadap masalah yang dihadapi manusia, suatu cara menggunakan informasi, menggunakan pengetahuan tentang bentuk dan ukuran, menggunakan pengetahuan tentang menghitung dan yang paling penting adalah memikirkan dalam diri manusia itu sendiri dalam melihat dan menggunakan hubunganhubungan. Berdasarkan pendapat Paling tersebut dapat disimpulkan bahwa untuk menemukan jawaban atas tiap masalah yang dihadapinya, manusia akan menggunakan: (1) informasi yang berkaitan dengan masalah yang dihadapi; (2) pengetahuan tentang bilangan, bentuk dan ukuran; (3) kemampuan untuk menghitung dan (4) kemampuan untuk mengingat dan menggunakan hubungan-hubungan. 
Matematika perlu diajarkan kepada siswa karena: (1) selalu digunakan dalam segala segi kehidupan; (2) semua bidang studi memerlukan keterampilan matematika yang sesuai; (3) merupakan sarana komunikasi yang kuat, singkat dan jelas; (4) dapat digunakan untuk menyajikan informasi dalam berbagai cara; (5) meningkatkan kemampuan berfikir logis, ketelitian dan kesadaran keruangan dan (6) memberikan kepuasan terhadap usaha memecahkan masalah yang menantang (Cockroft dalam Abdurrahman, 2007: 253). Berbagai alasan perlunya sekolah mengajarkan matematika kepada siswa pada hakikatnya dapat diringkaskan karena masalah kehidupan sehari-hari.

Menurut BNSP (2006: 148) mata pelajaran Matematika pada satuan pendidikan SD/MImeliputi aspek-aspek sebagai berikut.

1) Bilangan

Pembelajaran bilangan meliputi bilangan rasional, irrasional, pecahan, dan operasi bilangan.

2) Geometri dan Pengukuran

Pembelajaran geometri dan pengukuran meliputi bangun-bangun datar, bangun-bangun ruang, pengukuran panjang, pengukuran luas, pengukuran volume, pengukuran waktu, pengukuran temperatur, dan satuan ukur.

3) Pengolahan Data.

Pengolahan data memuat tentang pengumpulan data, diagram data, dan rerata.

Mata pelajaran matematika bertujuan agar peserta didik memiliki kemampuan sebagai berikut (BSNP, 2006: 148):

1) Memahami konsep matematika, menjelaskan keterkaitan antar konsep dan mengaplikasikan konsep atau algoritma, secara luwes, akurat, efisien dan tepat dalam pemecahan masalah

2) Menggunakan penalaran pada pola dan sifat, melakukan manipulasi matematika dalam membuat generalisasi, menyusun bukti atau menjelaskan gagasan dan pernyataan matematika

3) Memecahkan masalah yang meliputi kemampuan memahami masalah, merancang model matematika, menyelesaikan model dan menafsirkan solusi yang diperoleh

4) Mengomunikasikan gagasan dengan simbol, tabel, diagram atau media lain untuk memperjelas keadaan atau masalah.

5) Memiliki sikap menghargai kegunaan matematika dalam kehidupan yaitu memiliki rasa ingin tahu, perhatian dan minat dalam mempelajari matematika, serta sikap ulet dan percaya diri dalam pemecahan masalah. 


\section{BESTARI}

Vol. 16, No. 2, 2019

p-ISSN 1907-1337; e-ISSN 2807-6532

\section{Kemampuan Menghitung}

Menurut Sumadi Suryabrata (1998: 160), kemampuan biasanya diidentikkan dengan kemampuan individu dalam melakukan suatu aktifitas, yang menitikberatkan pada latihan dan performance atau apa yang latihan tertentu.

Woodworth dan Marquisdalam Suryabrata (2004: 161), mengungkapkan bahwa definisi ability (kemampuan) pada tiga arti, yaitu:

1) Achievement merupakan actual ability yang dapat diukur langsung dengan alat atau test tertentu.

2) Gapacity merupakan potential ability yang dapat diukur secara tidak langsung melalui pengukiran terhadap kecakapan individu, dimana kecakapan ini berkembang dengan perpaduan dasar dan training (pelatihan) yang intensif dan pengalaman.

bisa dilakukan oleh individu setelah mendapatkan Aptitude yaitu kualitas yang hanya dapat diungkapkan atau diukur dengan tes khusus yang di buat sengaja untuk itu.

Menurut pengertian diatas dapat disimpulkan bahwa kemampuan adalah kesanggupan dari seseorang atau potensi yang dimiliki seseorang untuk melakukan sesuatu.

Sunarto dan Hartono (2008: 120) menyatakan, bahwa kemampuan adalah daya untuk melakukan suatu tindakan sebagai hasil dari pembawaan dan latihan. Dari definisi kemampuan tersebut maka kemampuan seseorang dapat ditingkatkan dengan cara dilatih terus.

Menurut Guilforddalam Suryabrata (2004: 163) membagi kemampuan menjadi tiga jenis yaitu:

1) Kemampuan perceptual

Kemampuan perseptual adalah melalui kemampuan dalam mengadakan persepsi atau pengamatan antara lain mencakup faktor-faktor kepekaan indera, perhatian, kecepatan persepsi dan sebagainya.

2) Kemampuan Psikomotor

Kemampuan psikomotor adalah mencakup beberapa faktor antara lain: kekuatan, kecepatan gerak, ketelitian, keluwesan dan lain-lain.

3) Kemampuan Intelektual

Kemampuan Intelektual adalah kecenderungan yang menekankan pada kemampuan akal dimana mencakup beberapa 
faktor antara lain: ingatan, pengenalan, evaluasi, berfikir dan lainlain.

Dari pengertian-pengertian tersebut, dapat disimpulkan bahwa kemampuan (abilty) adalah kecakapan atau potensi menguasai suatu keahlian yang merupakan bawaan sejak lahir atau merupakan hasil latihan atau praktek dan digunakan untuk mengerjakan sesuatu yang diwujudkan melalui tindakannya.

Faktor yang mempengaruhi kemampuan menghitung (Hidayati, 2010: 1) mengemukan bahwa faktor yang mempengaruhi kemampuan berhitung anak adalah faktor internal dan faktor eksternal.

1) Faktor internal adalah faktor yang ada dalam diri anak tersebut berupa motivasi, kematangan, gaya belajar yang khas dari masingmasing anak, bakat yang ada dalam diri anak saat proses pembelajaran yang dilaksanakan didalam maupun diluar kelas.

2) Faktor eksternal adalah faktor dari luar diri anak seperti dari proses belajar mengajar yang dapat mempengaruhi rendahnya kemampuan berhitung anak misalnya pembelajaran yang kurang atraktif (menyenangkan), pembelajaran yang monoton dan media pembelajaran yang kurang menarik, pembelajaran yang kurang memfasilitasi keanekaragaman siswa. ${ }^{1}$

Menurut Dali S. Nagadalam Abdurrahman (2003: 253), berhitung atau menghitung adalah cabang matematika yang berkenaan dengan hubungan-hubungan bilangan nyata dengan perhitungan mereka terutama penjumlahan, pengurangan, perkalian dan pembagian. Berhitung merupakan bagian dari komponen mengenai konsep bilangan, lambang bilangan atau angka. Anak diharapkan mengenal konsep bilangan, lambang bilangan atau angka, sehingga mampu untuk berhitung dengan baik dan benar. Berhitung sangat dekat dengan kehidupan sehari-hari di sekitar tempat tinggal, sekolah, tempat umum dan di mana saja.

Menurut Aisyah, dkk (2007: 6.5) kemampuan berhitung merupakan salah satu kemampuan yang penting dalam kehidupan sehari- hari, dapat dikatakan bahwa semua aktivitas kehidupan semua manusia memerlukan kemampuan ini.

Dari pernyataan para ahli di atas, dapat disimpulkan bahwa kemampuan berhitung adalah kesanggupan dari seseorang atau potensi yang dimiliki seseorang untuk melakukan perhitungan dengan mengenal konsep dasar matematika seperti konsep bilangan, lambang bilangan atau angka, sehingga dapat melakukan perhitungan dengan baik dan benar.

\footnotetext{
${ }^{1}$ (http://cariilmupengetahuan.blogspot.co.id/2012/12/faktor-yang mempengaruhikemampuan.html diakses pada 13 maret 2017 pukul 13.00).
} 


\section{BESTARI}

Vol. 16, No. 2, 2019

p-ISSN 1907-1337; e-ISSN 2807-6532

Dalam Al-Qur'an Surat Yunus ayat 5, Allah SWT berfirman sebagai berikut: "Dia-lah yang menjadikan matahari bersinar dan bulan bercahaya dan ditetapkan-Nya manzilah-manzilah (tempat-tempat) bagi perjalanan bulan itu, supaya kamu mengetahui bilangan tahun dan perhitungan (waktu).Allah tidak menciptakan yang demikian itu melainkan dengan hak.Dia menjelaskan tanda-tanda (kebesaran-Nya) kepada orang-orang yang mengetahui." (Q.S. Yunus, 10: 5).

Dari ayat tersebut dapat diketahui bahwa kemampuan menghitung sangat penting agar manusia dapat mengetahui perhitungan tahun dan waktu dengan perjalanan matahari dan bulan.Tidak hanya perhitungan tentang waktu, tetapi juga tentang zakat atau pembagian hak waris, semua perkara tersebut membutuhkan perhitungan.Oleh karena itu manusia harus memiliki kemampuan untuk menghitung.

Kemampuan menghitung termasuk kedalam ranah kognitif sebab menyangkut aktivitas otak.Menurut Bloom dalam Anas Sudijono (2009: 49-50), segala upaya yang menyangkut aktivitas otak adalah termasuk dalam ranah kognitif.

Ranah kognitif terdiri atas enam level, termasuk di dalamnya yaitu:

1) Knowlage (pengetahuan), yaitu kemampuan menyebutkan atau menjelaskan kembali, yang termasuk di dalamnya yaitu mendefinisikan, mengidentifikasikan, mengetahui, menyebutkan, membuat kerangka, menggarisbawahi, menggambarkan, menjodohkan, dan memilih.

2) Comprehension (pemahaman atau persepsi), yaitu kemampuan memahami intruksi/masalah, menginterpretasikan dan menyatakan kembali dengan katakata sendiri, yang termasuk didalamnya yaitu Menerangkan, menjelaskan, menguraikan, membedakan, menginterpretasikan, merumuskan, memperkirakan, meramalkan, menggeneralisir, menterjemahkan, mengubah, memberi contoh, memperluas, menyatakan kembali, menganalogikan, merangkum.

3) Application (penerapan), yaitu Kemampuan menggunakan konsep dalam praktek atau situasi yang baru, yang termasuk Didalamnya yaitu Menerapkan, mengubah, menghitung, melengkapi, menemukan, membuktikan, menggunakan, mendemonstrasikan, memanipulasi, memodifikasi, menyesuaikan, menunjukkan, mengoperasikan, menyiapkan, menyediakan, menghasilkan.

4) Analysis (penguraian atau penjabaran), yaitu kemampuan memisahkan konsep kedalam beberapa komponen untuk memperoleh pemahaman yang lebih luas, yang termasuk didalamnya yaitu menganalisa, mendiskriminasikan, membuat skema, membedakan, mengkontraskan, memisahkan, membagi, menghubungkan, mengelompokkan, membedakan. 
5) Synthesis (pemaduan), yaitu kemampuan merangkai kembali atau menyusun kembali sehingga menjadi sesuatu yang baru, yang termasuk didalamnya yaitu mengkategorikan, mengkombinasi, memodifikasi, mendesain, mengarang, mencipta, merangkai, menulis kembali, menyimpulkan.

6) Evaluation (evaluasi), yaitu kemampuan untuk menilai sesuatu berdasarkan acuan yang berlaku, yang termasuk di dalamnya yaitu mengkaji ulang, mengkritik, menyimpulkan, membuktikan, memperhitungkan, mengkoreksi, melengkapi, dan menemukan.

Dari keenam level dari ranah kognitif di atas, berhitung atau menghitung termasuk ke dalam level Application (penerapan), yaitu Kemampuan menggunakan konsep dalam praktek atau situasi yang baru.

Penerapan atau pengaplikasian juga dapat diartikan sebagai kesanggupan seseorang untuk menerapkan atau menggunakan ide-ide umum, tata cara atau metode, prinsip-prinsip, rumus-rumus, teori-teori dan sebagainya dalam situasi yang baru dan konkret (Sudijono, 2009: 51).

\section{Konsep Media Konkret Koin Warna}

Secara umum media merupakan kata jamak dari "medium", yang berarti perantara atau pengantar.Kata media berlaku untuk berbagai kegiatan atau usaha, seperti media dalam penyampaian pesan, media pengantar magnet atau panas dalam bidang teknik.Istilah media digunakan juga dalam bidang pengajaran atau pendidikan sehingga istilahnya menjadi media pendidikan atau media pembelajaran (Sanjaya, 2010: 163).

Secara garis besar, media pembelajaran terdiri atas:

1) Media audio, media yang menggunakan unsur suara sebagai pembelajaran, seperti tape recorder dan radio.

2) Media visual, yaitu media yang menggunakan unsur pengelihatan seperti gambar, lukisan, foto, poster dan lain sebagainya.

3) Media audio visual, yaitu media gabungan dua unsur pendengaran dan pengelihatan seperti video, film, animasi bergerak dan lain sebagainya.

4) Orang, yaitu seseorang yang menyimpan informasi, pada dasarnya setiap orang dapat berperan sebagai sumber belajar.

5) Material (bahan), yaitu suatu format yang digunakan untuk menyimpan format pembelajaran, seperti buku paket, alat peraga, transparasi, video pembelajaran, slide dan lain-lain.

6) Alat (device), yaitu benda-benda yang berbentuk fisik sebagai perangkat kelas, yang berfungsi sebagai penyaji bahan pelajaran, seperti papan tulis, radio, OHP, Proyektor, televisi, VCD/DVD, tape recorder dan lain-lain. 


\section{BESTARI}

Vol. 16, No. 2, 2019

p-ISSN 1907-1337; e-ISSN 2807-6532

7) Teknik, yaitu cara atau prosedur yang digunakan seseorang dalam pembelajaran untuk mencapai tujuan pembelajaran, seperti ceramah, diskusi, seminar, permainan dan sejenisnya.

8) Latar (setting), yaitu berupa lingkungan sekitar yang berada di dalam maupun diluar kelas dan sekolahan, baik yang sengaja dirancang maupun tidak dirancang secara khusus untuk pembelajaran, seperti ruang kelas, studio, perpustakaan, aula, teman, kebun, pasar, toko, museum, kebun binatang dan lain-lain.

9) Media berbasis komputer, yaitu media berbasis teknologi. Biasanya media berbasis komputer erat kaitannya dengan internet. Dengan komputer dan internet, siswa dapat mencari informasi apapun yang mereka inginkan.

Menurut Ibrahim dan Nana Syaodih (2010: 115) berbagai jenis media pada dasarnya dapat digolongkan dalam tiga kelompok besar yaitu:

1) Media Cetak

2) Media Elektronik

3) Media Konkret (Objek nyata/realia).

Banyak batasan yang diberikan orang tentang media, AECT (Association of Education and Communication Technologi) memberi batasan tentang media sebagai segalabentuk dan saluran yang digunakan untuk menyampaikan pesan atau informasi. Sadiman dkk (2006: 6-7) berpendapat apapun batasan yang diberikan, ada persamaan diantara batasan tersebut yaitu bahwa media adalah segala sesuatu yang dapat digunakan untuk menyalurkan pesan dari pengirim ke penerima pesan sehingga dapat merangsang pikiran, perasaan, perhatian dan minat serta perhatian siswa sedemikian rupa sehingga proses belajar terjadi.

Menurut Sudjana dan Ahmad Rivai (2005: 2) manfaat media pengajaran dalam proses belajar siswa antara lain:

1) Pengajaran akan lebih menarik perhatian siswa sehingga dapat menumbuhkan motivasi belajar.

2) Bahan pengajaran akan lebih jelas maknanya sehingga dapat lebih dipahami oleh para siswa dan memungkinkan siswa menguasai tujuan pengajaran lebih baik.

3) Siswa lebih banyak melakukan kegiatan belajar, sebab tidak hanya mendengarkan uraian guru, tetapi juga aktivitas lain seperti mengamati, melakukan, mendemonstrasikan dan lain-lain.

Sedangkan menurut Azhar Arsyad (2000: 26) manfaat dari penggunaan media pengajaran di dalam proses belajar mengajar sebagai berikut: 
1) Media pengajaran dapat memperjelas penyajian pesan dan informasi sehingga dapat memperlancar dan meningkatkan proses dan hasil belajar.

2) Media pengajaran dapat meningkatkan dan mengarahkan perhatian anak sehingga dapat menimbulkan motivasi belajar, interaksi yang lebih langsung antara siswa dan lingkungannya dan kemungkinan siswa untuk belajar sendiri-sendiri sesuai dengan kemampuan dan minatnya.

3) Media pengajaran dapat mengatasi keterbatasan indera, ruang dan waktu.

Konkret berarti nyata dapat dibuktikan dalam pengertiannya. Menurut Ibrahim dan Syaodih (2010: 118), yang dimaksud media konkret yaitu " untuk mencapai hasil yang optimal dari proses belajar mengajar salah satu yang disarankan dalam digunakannya pula media yang bersifat langsung, bersifat nyata atau realia". Benda konkret yang sesungguhnya akan memberikan rangsangan yang amat penting bagi siswa dalam mempelajari berbagai hal, terutama yang menyangkut pengembangan keterampilan tertentu. Melalui penggunaan media konkret ini, kegiatan belajar mengajar dapat melibatkan semua indera siswa.

Media konkret memegang peranan yang cukup penting dalam proses pembelajaran, media konkret dapat memperlancar dan memperjelas penyampaian materi pembelajaran, media konkret dapat menumbuhkan minat siswa dan dapat memberikan hubungan antara isi materi pembelajaran dan dunia nyata, agar lebih efektif siswa sebaiknya berinteraksi langsung dengan media nyata meyakinkan terjadinya proses informasi.

Media konkret adalah segala sesuatu yang nyata dapat digunakan untuk menyalurkan pesan dari pengirim ke penerima sehingga dapat merangsang pikiran, perasaan, perhatian dan minat siswa sehingga proses pembelajaran dapat berjalan lebih efektif dan efesien menuju kepada tercapainya tujuan yang diharapkan.

Menurut Sadiman dkk (2006: 83), ditinjau dari kesiapan pengadaannya, media dikelompokkan dalam dua jenis yaitu:

1) Media jadi karena sudah merupakan komoditi perdagangan dan terdapat di pasaran luas dalam kedadaan siap pakai (media by utilization).

2) Media rancangan karena perlu dirancang dan dipersiapkan secara khusus untuk maksud atau tujuan pembelajaran tertentu (media by design).

Dalam penelitian ini, Media Konkret Koin Warna adalah media yang berbentuk kepingan koin warna-warni yang berfungsi sebagai alat bantu 


\section{BESTARI}

Vol. 16, No. 2, 2019

p-ISSN 1907-1337; e-ISSN 2807-6532

menghitung siswa. Media Konkret Koin Warna dapat berupa media jadi, karena koin warna yang akan dipakai dapat berupa koin maianan warnawarni atau dapat menggunakan kancing baju. Media Konkret Koin Warna juga dapat berupa media rancangan, karena dapat dibuat dengan kertas karton warna-warni yang dibentuk menyerupai koin.

Kelebihan dan kekurangan media konkret menurut Ibrahim dan Nana Syaodih (2010: 118) sebagai berikut:

1) Kelebihan Media Konkret

a) Dapat memberikan kesempatan semaksimal mungkin pada siswa untuk mempelajari sesuatu ataupun melaksanakan tugas-tugas dalam situasi nyata.

b) Memberikan kesempatan pada siswa untuk mengalami sendiri situasi yang sesungguhnya dan melatih keterampilan mereka dengan menggunakan sebanyak mungkin alat indera.

2) Kekurangan Media Konkret

a) Biaya yang diperlukan untuk mengadakan berbagai objek nyata kadang-kadang tidak sedikit, apalagi ditambah dengan kemungkinan kerusakan dalam menggunakannya.

b) Tidak selalu dapat memberikan semua gambaran dari objek yang sebenarnya seperti pembesaran, pemotongan dan gambar bagian demi bagian, sehingga pengajaran harus didukung pula dengan media lain.

Menurut Fathurrohman (2007: 72) Ada enam langkah yang bisa ditempuh guru dalam mengajar yang menggunakan media, yakni:

1) Merumuskan tujuan pengajaran dengan memanfaatkan media

2) Persiapan guru dengan cara memilih dan menetapkan media mana yang akan dimanfaatkan guna mencapai tujuan

3) Persiapan kelas, anak didik dan kelas dipersiapkan sebelum pelajaran dimulai. Guru harus dapat memotivasi mereka agar dapat menilai, menganalisis, menghayati pelajaran dengan menggunakan media pengajaran

4) Langkah penyajian pengajaran dan pemanfaatan media. Media diperankan guru untuk membantu tugasnya menjelaskan bahan pelajaran

5) Langkah kegiatan belajar siswa. Pemanfaatan media oleh siswa sendiri dengan mempraktekkannya atau oleh guru langsung baik di kelas atau diluar kelas

6) Langkah evaluasi pengajaran. Sampai sejauh mana tujuan pengajaran tercapai, sekaligus dapat dinilai sejauh mana penggunaan media sebagai alat bantu dapat menunjang keberhasilan proses belajar siswa. 


\section{METODE PENELITIAN}

Penelitian ini menggunakan metode Penelitian Tindakan Kelas (PTK) model Kurt Lewin. Teknik pengumpulan data yang digunakan adalah observasi, wawancara, teknik tes atau penilaian dan teknik analisis deskripsi. Penelitian ini bertujuan untuk meningkatkan hasil belajar dalam kemampuan menghitung siswa pada mata pelajaran Matematika pokok bahasan Operasi Hitung Campuran. Penelitian Tindakan Kelas di kelas II MIS Pasirlingga kec. Banjaranyar kab. Ciamis.

\section{HASIL PENELITIAN DAN PEMBAHASAN}

Pelaksanaan penelitian dilaksanakan selama dua siklus setiap siklusnya dua kali pertemuan, setiap siklus terdiri dari empat tahap, yaitu perencanaan, pelaksanaan, pengamatan, dan refleksi.

Penelitian siklus I Pertemuan pertama dilaksanakan pada tanggal 27 april 2017, dengan tujuan pembelajaran siswa dapat menghitung perkalian dan pembagian dengan bilangan dua angka dengan benar. Hasil pengamatan pada siklus I pertemuan pertama dapat diketahui bahwa untuk kemampuan guru dalam merancang RPP Matematika pada siklus I pertemuan pertama mencapai rata-rata 82,14; kemampuan guru dalam mengajar mencapai nilai rata-rata 84,53; dan hasil belajar kemampuan menghitung siswa mencapai nilai rata-rata 68,75 (43,75\%).

Secara klasikal, tingkat keberhasilan belajar siswa belum mencapai kriteria yang diharapkan. Namun jika dibandingkan dengan pembelajaran sebelumnya sudah mengalami peningkatan yakni dari nilai rata-rata hasil belajar pra siklus sebesar 67 dengan presentase $37,5 \%$ menjadi 68,75 dengan presentase $43,75 \%$.

Berdasarkan hasil penelitian dan temuan data mengenai hasil belajar kemampuan menghitung siswa pokok bahasan Operasi Hitung Campuran, belum memenuhi target. Kendala yang dihadapi pada siklus I pertemuan pertama yaitu siswa belum terbiasa dengan kondisi belajar baru dan masih merasa canggung untuk berkomunikasi, siswa terlalu tergesa-gesa dalam mengerjakan soal latihan menggunakan media konkret koin warna,langkah-langkah kegiatan pembelajaran kurang tersusun rapi yang mengakibatkan siswa kurang memahami intruksi guru serta dalam pengaturan waktu harus diperhatikan sehingga dalam proses pembelajaran tepat waktu. Kendala yang ditemukan pada proses siklus I pertemuan pertama didiskusikan oleh peneliti dan observer, karena hasil tindakan pembelajaran ini akan dijadikan bahan refleksi bagi peneliti untuk merancang proses pembelajaran siklus I pertemuan kedua.

Pada siklus I pertemuan kedua dilaksanakan pada tanggal 29 April 2017, dengan tujuan pembelajaran siswa dapat menentukan urutan 


\section{BESTARI}

Vol. 16, No. 2, 2019

p-ISSN 1907-1337; e-ISSN 2807-6532

pengerjaan hitung penjumlahan, pengurangan, perkalian dan pembagian dengan benar. Hasil pengamatan pada siklus I pertemuan kedua dapat diketahui bahwa untuk kemampuan guru dalam merancang Rencana Pelaksanaan Pembelajaran (RPP) Matematika mencapai rata-rata 85; Kemampuan guru dalam mengajar mencapai nilai rata-rata 87,96; dan hasil belajar siswa mencapai nilai rata-rata 69,5 (50\%). Berdasarkan data yang diperoleh dari siklus I pertemuan kedua, dapat diketahui bahwa nilai yang diperoleh meningkat dari sebelumnya. Namun, peneliti ingin memantapkan mengenai peningkatan hasil belajar tersebut. Maka dari itu peneliti memutuskan untuk melakukan siklus II.

Pada siklus II pertemuan pertama dilaksanakan pada tanggal o4 mei 2017 dengan tujuan pembelajaran siswa dapat menghitung operasi hitung campuran penjumlahan, pengurangan, perkalian dan pembagian dengan benar. Hasil pengamatan siklus II pertemuan pertama dapat diketahui bahwa untuk kemampuan guru dalam menyusun Rencana Pelaksanaan Pembelajaran (RPP) Matematika mencapai rata-rata 88,39; Kemampuan guru dalam mengajar mencapai nilai rata-rata 89,21; dan hasil belajar kemampuan menghitung siswa mencapai nilai rata-rata 74,375 (75\%). Berdasarkan data yang diperoleh dari siklus I hingga siklus II terus meningkat, namun belum memenuhi target maka dari itu peneliti memutuskan untuk melakukan siklus II pertemuan kedua.

Pada siklus II pertemuan kedua dilaksanakan pada tanggal o6 mei 2017 dengan tujuan pembelajaran siswa dapat memecahkan masalah sehari-hari yang melibatkan penjumlahan, pengurangan, perkalian dan pembagian dengan tepat. Hasil pengamatan siklus II pertemuan kedua dapat diketahui bahwa untuk kemampuan guru dalam menyusun Rencana Pelaksanaan Pembelajaran (RPP) Matematika mencapai ratarata 90,17; Kemampuan guru dalam mengajar mencapai nilai rata-rata 90,78; dan hasil belajar kemampuan menghitung siswa mencapai nilai rata-rata $80(87,5 \%)$. Berdasarkan data yang diperoleh dari siklus I hingga siklus II terus meningkat, oleh karena itu penelitian dihentikan karena telah mencapai target.

Penelitian tindakan kelas ini dilaksanakan sebanyak 2 siklus, satu siklus dilaksanakan dua kali pertemuan. Penelitian ini telah dilaksanakan di MIS Pasirlingga Kecamatan Banjaranyar Kabupaten Ciamis pada semester II tahun pelajaran 2016/2017.

Sebelum mengadakan penelitian tindakan kelas, peneliti berdiskusi dengan guru guru kelas II MIS Pasirlingga Kecamatan Banjaranyar Kabupaten Ciamis, untuk meminta nilai hasil belajar siswa. Nilai rata-rata hasil belajar siswa pra tindakan adalah 67 dengan presentase $37,5 \%$. Berdasarkan nilai tersebut peneliti bermaksud melakukan penelitian tindakan kelas mengenai penggunaan media konkret koin warna untuk meningkatkan kemampuan menghitung siswa pada mata pelajaran 
Matematika pokok bahasan Operasi Hitung Campuran di kelas II MIS Pasirlingga Kecamatan Banjaranyar Kabupaten Ciamis.

Berdasarkan hasil penelitian tindakan kelas yang telah dilaksanakan mengenai penggunaan media konkret koin warna untuk meningkatkan kemampuan menghitung siswa pada mata pelajaran Matematika pokok bahasan Operasi Hitung Campuran di kelas II MIS Pasirlingga Kecamatan Banjaranyar Kabupaten Ciamis pada pembelajaran siklus I dan siklus II maka dapat diketahui:

a. Peningkatan kemampuan guru dalam merancang Rencana Pelaksanaan Pembelajaran (RPP) dari siklus I pertemuan pertama dengan rata-rata 82,14 ke siklus I pertemuan kedua yaitu menjadi 85 demikian pula dari siklus II pertemuan pertama dengan rata-rata 88,39 ke siklus II pertemuan kedua mengalami peningkatan yaitu menjadi 90,17.

b. Kinerja guru dalam melaksanakan pembelajaran juga berpengaruh terhadap hasil belajar siswa. Dari dua siklus yang telah dilaksanakan dalam penelitian tindakan kelas ini, pelaksanaan pembelajaran semakin baik, hal ini dilihat berdasarkan penilaian observer pada pembelajaran siklus I pertemuan pertama dengan nilai rata-rata 84,53, siklus I pertemuan kedua dengan nilai rata-rata 87,96, siklus II pertemuan pertama dengan nilai rata-rata 89,21 dan siklus II pertemuan kedua mencapai nilai rata-rata 90,78.

c. Hasil belajar dalam kemampuan menghitung siswa juga dipengaruhi oleh kemampuan guru dalam menyusun RPP dan dalam melaksanakan pembelajaran. Berdasarkan penelitian tindakan kelas yang telah dilakukan hasilnya semakin meningkat. Dengan nilai rata-rata siswa pra tindakan 67 dengan presentase $37,5 \%$, hasil tes belajar siswa siklus I pertemuan pertama dengan rata-rata 68,75 dengan presentase $43,75 \%$, siklus I pertemuan kedua dengan rata-rata 69,5 dengan presentse 50\%, siklus II pertemuan pertama mencapai rata-rata 74,375 dengan presentase $75 \%$ dan siklus II pertemuan kedua mencapai nilai rata-rata $80(87,5 \%)$

Berdasarkan temuan dan proses yang dilaksanakan pada setiap siklus diperoleh peningkatan terhadap kinerja guru, kinerja siswa, dan hasil belajar dalam kemampuan menghitung siswa. Peningkatan terhadap siklus tersebut membuktikan bahwa penggunaan media konkret koin warna (kancing) dalam pembelajaran Matematika pokok bahasan Operasi Hitung Campuran di kelas II MIS Pasirlingga Kecamatan Banjaranyar Kabupaten Ciamis dapat meningkatkan hasil belajar dalam kemampuan menghitung siswa. Adapun rekapitulasi peningkatan tersebut dapat dilihat dalam grafik sebagai berikut: 


\section{BESTARI}

Vol. 16, No. 2, 2019

p-ISSN 1907-1337; e-ISSN 2807-6532

Grafik peningkatan hasil dari siklus I sampai siklus II

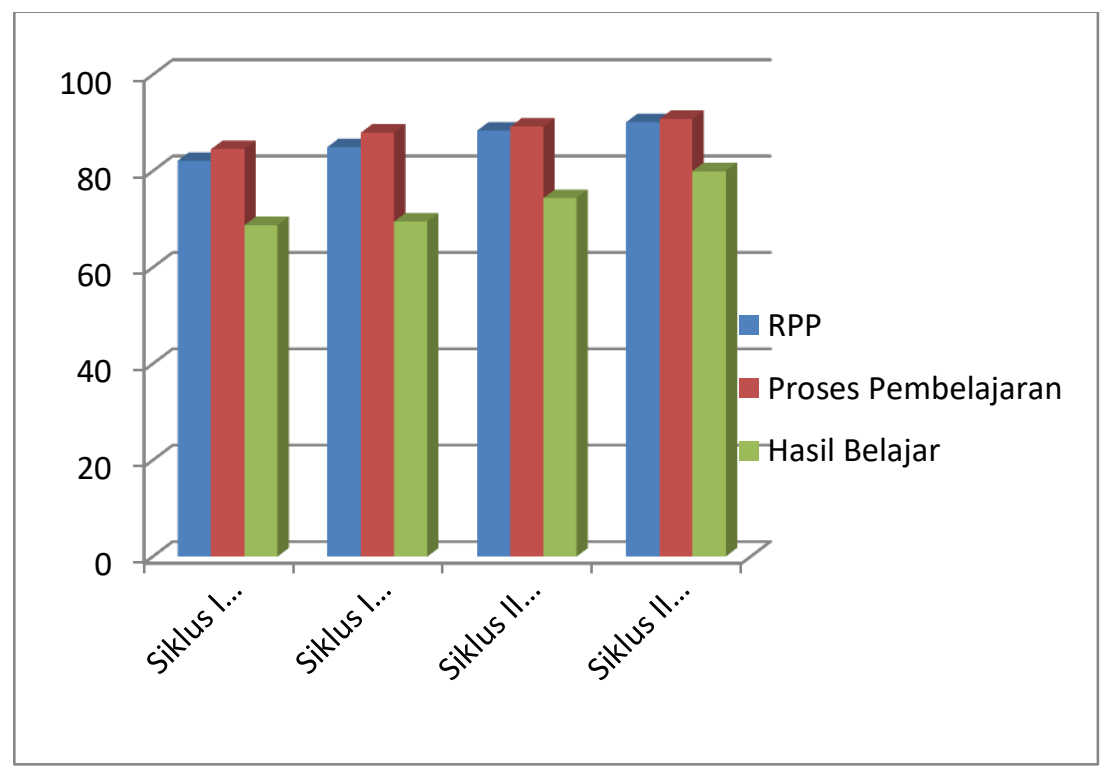

Dari grafik rekapitulasi nilai antar siklus tersebut maka dapat disimpulkan bahwa penggunaan media konkret koin warna (kancing) dalam upaya meningkatkan kemampuan menghitung siswa pada mata pelajaran Matematika pokok bahasan Operasi Hitung Campuran dikatakan berhasil.

\section{KESIMPULAN}

Berdasarkan hasil penelitian tindakan kelas yang dilakukan peneliti pada pembelajaran Matematika pokok bahasan Operasi Hitung Campuran dengan menggunakan media konkret koin warna (kancing) yang dilaksanakan di kelas II MIS Pasirlingga Kecamatan Banjaranyar Kabupaten Ciamis, maka peneliti menyimpulkan hal-hal sebagai berikut: (1) Perencanaan pembelajaran Matematika pokok bahasan Operasi Hitung Campuran dengan menggunakan media konkret koin warna di kelas II MIS Pasirlingga Kecamatan Banjaranyar Kabupaten Ciamis yang dilakukan oleh guru telah sesuai dengan acuan standar KTSP. Perencanaan pembelajaran pada siklus I pertemuan pertama mencapai nilai rata-rata 82,14 dengan presentase $82,14 \%$ dan siklus I pertemuan kedua mencapai nilai rata-rata 85 dengan presentase $85 \%$. Pada siklus II pertemuan I mencapai nilai rata-rata 88,39 dengan presentase $88,39 \%$ dan siklus II pertemuan kedua mencapai nilai rata-rata 90,17 dengan presentase 90,17\% Artinya guru mengalami peningkatan kemampuan 
dalam penyusunan perencanaan pembelajaran selama pelaksanaan tindakan. (2) Pelaksanaan pembelajaran Matematika pokok bahasan Operasi Hitung Campuran dengan menggunakan media konkret koin warna di kelas II MIS Pasirlingga Kecamatan Banjaranyar Kabupaten Ciamis yang dilakukan oleh guru telah menunjukkan kegiatan pembelajaran yang mengacu kepada pembelajaran aktif, inovatif, kreatif, efektif dan menyenangkan. Kemampuan guru dalam melaksanakan pembelajaran terus mengalami peningkatan. Pada siklus I pertemuan pertama kemampuan guru dalam mengajar mencapai nilai rata-rata 84,53 dengan presentase $84,53 \%$ dan siklus I pertemuan keduamencapai nilai rat-rata 87,96 dengan presentase $87,96 \%$. Pada siklus II pertemuan pertama mencapai nilai rata-rata 89,21 dengan presentase $89,21 \%$ dan siklus II pertemuan kedua mencapai nilai rata-rata 90,78 dengan presentase 90,78\%. Hal ini menunjukkan bahwa guru mampu meningkatkan kemampuan melaksanakan pembelajaran selama pemberian tindakan. (3) Hasil belajar siswa kelas II MIS Pasirlingga Kecamatan Banjaranyar Kabupaten Ciamis setelah mengikuti pembelajaran Matematika pokok bahasan Operasi Hitung Campuran dengan menggunakan media konkret koin warna mengalami peningkatan. Presentase hasil belajar kemampuan menghitung siswa pada siklus I pertemuan pertama mencapai nilai rata-rata 68,75 dengan presentase $43,75 \%$ dan siklus I pertemuan kedua mencapai nilai rata-rata 69,5 dengan presentase $50 \%$. Pada siklus II pertemuan pertama mencapai nilai rata-rata 74,375 dengan presentase $75 \%$ dan siklus II pertemuan kedua mecapai nilai rata-rata 80 dengan presentase $87,5 \%$. Dengan demikian dapat disimpulkan bahwa upaya meningkatan hasil belajar kemampuan menghitung siswa untuk menggunakan media konkret koin warna berhasil.

\section{DAFTAR PUSTAKA}

Abdurrahman, Mulyono. (2003). Pendidikan Bagi Anak Berkesulitan Belajar. Jakarta: Rineka Cipta.

Arikunto. Suharsimi. (1998). Prosedur Penelitian: Suatu Pendekatan Praktek. Jakarta: Rineka Cipta.

----------(2007). Penelitian Tindakan Kelas. Bumi Aksara, Cetakan Keempat, Jakarta.

Arsyad, Azhar. (2000). Media Pengajaran. Jakarta: Raja Grafindo Persada.

Depdiknas. (2006). Kurikulum Tingkat Satuan Pendidikan: Kerangka Dasar. Pusat Kurikulum, Jakarta. 


\section{BESTARI}

Vol. 16, No. 2, 2019

p-ISSN 1907-1337; e-ISSN 2807-6532

Fathurrohman, Pupuh. (2007). Strategi Belajar Mengajar. Bandung: Refika Aditama.

Hanafiah, Nanang, dkk. (2010). Konsep Strategi Pembelajaran. PT Refika Aditama: Bandung.

Heruman. (2007). Model Pembelajaran Matematika di Sekolah Dasar. Bandung: Remaja Rosdakarya.

Ibrahim, R \& Nana Syaodih S. (2010). Perencanaan Pengajaran. Jakarta: Rineka Cipta.

Jumali, M., et.al. (2008). Landasan Pendidikan. Surakarta: Muhammadiyah University Press.

Mulyanti, Yulis. (2012). Upaya Meningkatkan Prestasi Belajar Matematika pada Materi Penjumlahan melalui Penggunaan Alat Peraga di Kelas II B MI GUPPI O1 Jembang Banjarnegara. Skripsi. Fakultas Tarbiyah dan Keguruan UIN Sunan Kalijaga, Yogyakarta.

Nyimas Aisyiah. (2007). Pengembangan Pembelajaran Matematika SD. Jakarta:Dirjen Dikti Depdiknas.

Prianto, Heri. (2013). Peningkatan hasil belajar matematika melalui pendekata matematika realistic (PMR) siswa kelas II A MI AlHIKAM Geger Madiun Tahun Pelajaran 2012/2013 Penelitian Tindakan Kelas. Jurnal Ilmiah Pendidikan, 01 (01), 91-104.

Purnomosidi dkk. (2008). Matematika 2. Jakarta: Pusat Perbukuan Departemen Pendidikan Nasional.

Sadiman, Arief S.,et.al. (2006). Media Pendidikan. Jakarta: Raja Grafindo Persada.

Sanjaya, Wina. (2009). Penelitian Tindakan Kelas.Jakarta: Kencana Prenada Media Group. Cetakan Keenam.

. (2010). Strategi Pembelajaran. Jakarta: Prenada media group.

Sudijono, Anas. (2009). Pengantar Evaluasi Pendidikan. Jakarta: Rajawali Pres.

Soehendro, Bambang. 2006. Standar Isi Untuk Satuan Pendidikan Dasar dan Menengah. BNSP, Jakarta.

Sudjana, Nana \& Ahmad Rivai. (2005). Media Pengajaran. Bandung: Sinar Baru.

Sudjana, Nana. (2005). Penilaian Hasil Proses Belajar Mengajar.Bandung: Remaja Rosdakarya.

Sugiyono. (2009) .Statistik Untuk Penelitian.Bandung: Alfabeta. Cetakan Kesepuluh. 
Sunarto \& Agung Hartono. (2008). Perkembangan Peserta Didik. Jakarta: PT Rineka Cipta.

Sunaryo, Wowo. (2011). Taksonomi Berfikir. Bandung: Remaja Rosdakarya.

Suryabrata, Sumadi. (1998). Psikologi Pendidikan. Jakarta: Raja Grafindo Persada. (2004). Psikologi Pendidikan. Jakarta: PT Raja Grafindo Persada.

Tim Redaksi. (2008). Kamus Besar Bahasa Indonesia. Pusat Bahasa, Jakarta. 